\title{
Determination of proximate composition, amino acids, minerals and phytochemical profile of Cassava (Manihot esculenta) peel from sweet cassava variety grown in Yobe State of North Eastern Nigeria \\ ${ }^{1}$ Amaza I. B.

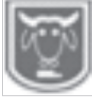 \\ Animal Science Department, Federal University Gashua, Yobe State Nigeria \\ Corresponding author: Iliyaamaza20@gmail.com
}

Abstract

The proximate composition, amino acid, mineral, and Phytochemical content of Cassava peel was determined. The peels were found to contain $8.70 \%$ moisture, $4.89 \%$ crude protein, $8.75 \%$ crude fiber, $2.15 \%$ crude fat, $8.93 \%$ ash. Nitrogen free extract and metabolizable energy values were $66.56 \%$ and $2717.96 \mathrm{kcal}$, respectively. The results of amino acid content revealed that the histidine and tyrosine are the most limiting amino acid with values of $0.005 \%$ each. Essential amino acids such as lysine, leucine, methionine and Isoleucine with values of 0.032, 0.067, 0.076 and 0.070\% were low. Mineral profile revealed that magnesium $(913.74 \mathrm{mg} / \mathrm{kg}$ ) and iron $(111.50 \mathrm{mg} / \mathrm{kg})$ as the most abundant mineral. Concentrations of phytochemicals were 26.06, 699.8, 0.063, 24.81,8.37,1457mg/100g and 2.84 for saponin, tannin, hydrogen cyanide, phytate, trypsin inhibitors, alkaloid and oxalate respectively. Based on results of this study, cassava peel can be potential source of energy; however, protein and amino acids contents are very low. It is therefore, recommended that feeding of animal with cassava peel based diets be supplemented with good quality amino acids.

Keywords: Cassava peel, Proximate, Amino acid, Minerals, Phytochemical

La Détermination de la composition immédiate, des acides aminés, des minéraux et du profil phytochimique de la peau de manidis (Manihotesculenta) provenant de variétés de manioc sucrée cultivées dans l'État de Yobe, dans le nord-est du Nigeria

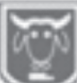

Résumé

$\overline{\text { La composition immédiate, l'acide aminé, la teneur minérale et phytochimique de la peau de }}$ manioc ont été déterminées. Les pelures contenaient $8,70 \%$ d'humidité, 4,89\% de protéines brutes, 8,75\% de fibres brutes, 2,15\% de matières grasses brutes, 8,93\% de cendres. L'extrait sans azote et les valeurs énergétiques métabolisables étaient respectivement de $66,56 \%$ et 2717,96 kcal. Les résultats de la teneur en acides aminés ont révélé que l'histidine et la tyrosine sont l'acide aminé le plus limitant avec des valeurs de 0,005\% chacune. Les acides aminés essentiels tels que la lysine, la leucine, la méthionine et l'isoleucine avec des valeurs de 0,032, 0,067, 0,076 et 0,070\% étaient faibles. Le profil minéral a indiqué que le magnésium $(913.74 \mathrm{mg} / \mathrm{kg})$ et le fer $(111.50 \mathrm{mg} / \mathrm{kg})$ sont des minéraux les plus abondants. Les concentrations de produits phytochimiques étaient de 26,06, 699,8, 0,063, $24,81,8,37,1457 \mathrm{mg} / 100 \mathrm{~g}$ et 2,84 pour la saponine, le tanin, le cyanure d'hydrogène, le phytate, les inhibiteurs de la trypsine, l'alcalö̈de et l'oxalate respectivement. D'après les résultats de cette étude, la peau de manioc peut être une source potentielle d'énergie; cependant, la teneur en protéines et en acides aminés est très faible. Il est donc recommandé que l'alimentation des animaux avec des régimes à base de pelures de manioc soit complétée par des acides aminés de bonne qualité.

Mots-clés: Pelure de manioc, Proximate, Acides aminés, Minéraux, Phytochimie 


\section{Introduction}

Climate change is one of the key drivers of the challenges confronting the North Eastern Nigeria; it has impacted negatively on economic and social fabrics of the population. According to Ambrose et al. (2017) climate change poses great danger as it leads to loss of plants and animals as well as depletion of biodiversity. Drought and soil fertility depletion are common phenomena in Yobe and regarded as the fundamental biophysical cause for declining per capita food production (FAO, ICRISAT.2019). According to the (NBS, 2010, UNDP, 2018), Nigeria's multifaceted poverty index reported, Yobe state was ranked as one of the poorest states in the North with multifaceted poverty index (MPI) scores of 0.635 . Yobe state also has the highest number of malnutrition cases in Nigeria (WFP, 2017). As a mitigation strategy to the threats posed by climate change, farming communities in some parts of Yobe state have since switched to cultivation of cassava. Cassava, are more robust in the face of higher temperature and increased drought stress, making it a potentially valuable food source (ILRI, 2015). Enormous cassava peels are generated as by product from Cassava processing and holds enormous potential as feed resource for livestock if properly processed (ILRI, 2015). It was reported to be cost-effective in compounding poultry feeds (Etchu et al., 2015). Thus, with emerging technologies of drying, grating and preserving cassava peels, it holds the key to providing a readily available and sustainable source of feeding for domestic animals (Ayomide, 2018). Nutrient analysis enables livestock producers to make optimum use of nutrient, help researchers relate feed to animals' performance and reduce production costs. Nutrient values of cassava peel are listed in ingredient composition tables and reported in the scientific literature. However, in many instances, these values have been reported to be influenced by so many factors such as variety, the age of the harvested crop, soil and climatic conditions (Apeh et al., 2017). Information gap existed on nutrient and phytochemical profile of cassava peels from tubers grown in Yobe State of North Eastern Nigeria. This study was undertaken to bridge the information gap by providing baseline information for researcher, livestock farmers and policy formulators

\section{Materials and methods Source and preparation of cassava peel}

Cassava tubers were collected from Garbi village in Nguru local government area of Yobe State Nigeria. The site was selected based on high production of cassava. Nguru town is the head quarter of Nguru local government area in Yobe state, North Eastern Nigeria. It is located near river Hadejia at $12^{\circ} 52^{\prime} 45^{\prime \prime} \mathrm{N}$ to $10^{\circ} 27^{\prime} 09^{\prime \prime} \mathrm{E}$. It has population of 150, 632 and an area of 916 sq. km (NPC, 2006). The tubers were washed and peeled with sharp knife to ensure that only outer cover of the tuber was removed. The peels were sun dried for a period of 7 days, milled into fine particle sizes using Laboratory mill (Arthur Thomas, USA), sieved via $1 \mathrm{~mm}$ sieve_and were packaged in airtight plastic bags prior to analyses.

\section{Laboratory analysis}

Triplicate homogeneous representative samples of sweet cassava peel which was kept in properly labeled and tightly sealed clean plastic containers were analyzed. Analyses were conducted at $\mathrm{T} \& \mathrm{D}$ Laboratories Elim Vision Plaza, opposite $2^{\text {nd }}$ Gate University of Ibadan.

\section{Chemical analysis}

Determination of proximate composition

Samples of the cassava peel were subjected to proximate analyses according to the methods of AOAC (1990). The parameters determined included moisture content $(\mathrm{MC})$, crude protein $(\mathrm{CP})$, crude fiber (CF), ether extract (EE) and ash content (AC). The nitrogen free extracts (NFE) was 
determined by difference. NFE $(\%)=100$ $(\% \mathrm{CP}+\% \mathrm{CF}+\%$ ash $+\% \mathrm{EE})$.

The metabolizable energy (ME) was calculated from Pauzenga, (1985) formula as follows: $\mathrm{ME}(\mathrm{kcal} / \mathrm{kg} \mathrm{DM})=(37 \mathrm{x} \% \mathrm{CP})$ $+(81 \mathrm{x} \%$ fat $)+(35.5 \mathrm{x} \% \mathrm{NFE})$.

\section{Determination of amino acids}

The amino acid content of cassava peel was determined using the method described by AOAC, (1990). Samples were dried to constant weight, defatted, hydrolyzed, evaporated in a rotary evaporator and loaded into the Technicon Sequential Multisample (TSM) amino Acid analyzer (TSM) using ion-exchange chromatography (Technicon Instruments Corporation, Dublin, Ireland).

\section{Determination of saponin}

Saponin content of cassava peel was determined according to method described by $\operatorname{Sim}$ (2011). Saponin solution was prepared by dissolving $10 \mathrm{mg}$ of diosgenin, $16 \mathrm{ml}$ of methanol and $4 \mathrm{ml}$ of distilled water. Aliquots were taken in tube and vanillin reagent $8 \%(0.25 \mathrm{ml})$ was added. Thereafter $72 \% \mathrm{v} / \mathrm{v}$, of sulphuric acid $(2.5$ $\mathrm{ml}$ ) was added slowly on the inner wall of tube. The solutions were thoroughly mixed and the tubes were transferred to a water bath set at $60^{\circ} \mathrm{C}$. After 10 minutes of incubation, the tubes were cooled in ice cold water bath for 3-4 minutes. Thereafter $0.1 \mathrm{~g}$ of freeze dried sample was dissolved in aqueous methanol $80 \%(0.1 \mathrm{ml}) .0 .25 \mathrm{ml}$ of aliquot was taken for spectrophotometric determination for total saponin at $544 \mathrm{~nm}$.

\section{Determination of tannin content}

Tannins were determined using the method of Paul et al. (1988). $0.2 \mathrm{~g}$ of each sample was weighed into a beaker and soaked with solvent mixture $(80 \mathrm{ml}$ of acetone and $20 \mathrm{ml}$ of glacial acetic acid) for 5 hours to extract tannin. The filtrate was removed and the sample was filtered through a double layer filter paper to obtain the filtrate. A set of standard solution of tannic acid was prepared ranging from 0 to $10 \mathrm{ppm}$. The absorbencies of the standard solution as well as that of the filtrates were read at 720 nm on a spectronic 20 .

\section{Hydrogen cyanide determination}

The hydrogen cyanide content was determined according to method described by FIIRO, (2004). Twenty (20) grams of sweet cassava was weighed and transferred into a $1000 \mathrm{~cm}^{3}$ beaker containing $100 \mathrm{~cm}^{3}$ of distilled water, $200 \mathrm{~cm}^{3}$ of phosphate buffer (pH 6.0) and $10 \mathrm{~cm}^{3}$ of $2 \%$ mercuric chloride solution and left overnight. The sample was then transferred to $500 \mathrm{~cm}^{3}$ round bottom flask and $5.0 \mathrm{~g}$ of hydrated stannous chloride was added to the sample and steam distillation method was used to separate the hydrocyanic acid from the prepared sample. After the mixture was heated by steam distillation, the released hydrogen cyanide was collected in a conical flask containing $50 \mathrm{~cm}^{3}$ of $1 \%$ alcoholic sodium hydroxyl $(\mathrm{NaOH})$ solution until the volume of the distillate was $200 \mathrm{~cm}^{3}$. The distillate was then titrated against $0.02 \mathrm{M}$ AgNO3 using $1 \mathrm{~cm}^{3}$ of freshly prepared $0.5 \% \mathrm{w} / \mathrm{v}$ dithizone in ethanol as indicator and the amount of cyanide in the sample was determined. The end point of the titration was accommodated with a color change of the indicator from red to purple.

Concentration of cyanide $=$

Titre value $\mathrm{x} 0.52 \times 1000$

Weight of the sample taken

\section{Determination of phytate}

Phytate was determined using the method of Maga (1983). 2 grams of each sample were weighed. $100 \mathrm{ml}$ of $2 \%$ concentrated hydrochloric acid was used to soak each sample into conical flask for 3 hours and filtered through a double layer of hardened filter paper. $50 \mathrm{ml}$ of each filtrate was placed in $250 \mathrm{ml}$ beaker and $107 \mathrm{ml}$ of distilled water was added in each case to give proper acidity. $10 \mathrm{ml}$ of $0.3 \%$ ammonium thiocyanate solution was added into each solution as indicator. This was titrated with 
standard iron (III) chloride solution which contained $0.00495 \mathrm{~g}$ iron per $\mathrm{ml}$. The end point was slightly brownish-yellow which persisted for 5 minutes.

\section{Alkaloid determination}

$0.5 \mathrm{~g}$ of cassava peel was weighed with sensitive digital scale and $20 \mathrm{ml}$ of $20 \%$ Acetic acid was added to it in $100 \mathrm{ml}$ beaker. The beakers were covered and allowed to stand for 4 hours. it was later filtered and placed in water bath to reduce the weight to one quarter. Concentrated Ammonium hydroxide was added drop wise until precipitation was complete. It was then collected by filtration and weighed.

\section{Oxalate determination}

The total oxalate was determined according to the procedure of Fasset, (1996). The extraction was done by weighing $1 \mathrm{~g}$ of each sample and soaked with $100 \mathrm{ml}$ of distilled water. It was allowed to stand for 3 hours and each was filtered through a double layer of filter paper. 10, 20, 30, 40 and 50 ppm standard solution of oxalic acid was prepared and read on the spectrophotometer at $420 \mathrm{~nm}$ for the absorbance. The absorbance of filtrate from each sample were also read on the Spectronic 20

\section{Determination of trypsin inhibitor activity}

Trypsin inhibitor of the samples was determined by the method of Liener, (1979). 0.2 gram of each sample was weighed into a screw-cap centrifuge tube. $10 \mathrm{ml}$ of $0.1 \mathrm{M}$ phosphate buffer was added and the contents were shaken at room temperature for 1 hour on a UDY shaker. The suspension obtained was centrifuged at $5000 \mathrm{rpm}$ for $5 \mathrm{~min}$ and filtered through Whatman No.42 filter paper. The volume of each was adjusted to $2 \mathrm{ml}$ with phosphate buffer. The test tubes were placed in water bath, maintained at $37^{\circ} \mathrm{C}$ and $6 \mathrm{ml}$ of $5 \%$ tricarboxylic acid (TCA) solution was added to one of the tubes to serve as a blank. $2 \mathrm{ml}$ of casein solution was added to all the tubes previously kept at $37^{\circ} \mathrm{C}$ and were incubated for $20 \mathrm{~min}$. The reaction was stopped after 20 minutes by adding $6 \mathrm{ml}$ of TCA solution to the experimental tubes and then shaken. The reaction was allowed to proceed for 1 hour at room temperature. The mixture was filtered through Whatman No.42 filter paper and the absorbance of filtrate from sample and trypsin standard solutions were read at $280 \mathrm{~nm}$.

\section{Mineral determination}

The sodium and potassium content was determined using a flame photometer while calcium, manganese, magnesium, iron, copper, lead, aluminum, phosphorus and zinc were determined by ashing the samples with a mixture of hydrochloric acid and nitric acid, followed by flaming in Atomic Absorption Spectrophotometer (Philip Analytica PU 9100X) using different lamps according to AOAC (1990).

\section{Computed protein efficiency ratio}

The C-PER was calculated using the equation described by Alsmeyer et al. (1974.)

$\mathrm{C}-\mathrm{PER}=-0.684+0.456(\mathrm{LEU})-0.047$

(PRO)

$$
\begin{aligned}
& 0.047(0.072) \\
& \text { C-PER=0.711 }
\end{aligned}
$$

\section{Statistical analysis}

All the results were expressed as mean \pm standard deviation of triplicate samples.

\section{Results and discussion}

The proximate composition of cassava peel is presented in Table 1. The moisture (MC), crude protein $(\mathrm{CP})$, crude fiber $(\mathrm{CF})$, ether extract (EE), ash and nitrogen free extract (NFE) values were 8.70, 4.89, 8.75, 2.15, 8.93 and $66.56 \%$ respectively, while the Metabolizable energy value of 2717.96 $(\mathrm{kcal} / \mathrm{kg})$ was recorded. These values are comparable to values of $8.73,4.21$ and $8.46 \%$ for moisture, crude protein and crude fiber reported by Ezekiel et al. (2010) but higher than the values reported by Monday et al. (2017) in a study conducted on three varieties of sweet cassava peels (TMS 


\section{Amaza}

98/0581, TMS98/0505 and TMS 98/0524 grown in Apa, Otupko and Ushongo area of Benue state, Nigeria. The NFE value recorded in this study $(66.56 \%)$ showed that cassava peel contains appreciable level of carbohydrates and can serve as energy source. The ether extract, ash and crude fiber content were higher than the values reported by Christopher et al. (2016) in a study conducted on three cultivars of waste cassava peels (NR 07/0220, TMS/419, TMS/3055). However, the crude protein value of $4.89 \%$ and ether extract $(2.15 \%)$ fell within the range values of 3.7 to 5.9 and 0.0 to $3.3 \%$ for crude protein and ether extract reported by INRA et al. (2012b). Olugbenga (2020) and Heuze (2012) however, reported higher values of crude protein $(5.48 \%)$, crude fiber $(10.50 \%)$ nitrogen free extract values $(70.46 \%)$ and $5.2,14.0$ and $70.9 \%$ when compared with values reported in this study. The variation observed may be attributed to cultivar, agronomic practices and environmental factors. Cadavid et al. (1998) reported that cultivar and agronomic practices influence the composition of cassava products. The high fiber, low energy and protein values recorded in this study are in agreement with earlier reports of (Smith 1992, Sogunle et al. 2009)). The low- fat and high fiber contents accounted for low energy in cassava peel meal. All cassava cultivars presently grown in Nigeria are low in essential minerals, vitamins, and protein content (Njoku et al., 2014).

Table 1: Proximate composition sweet Cassava peels (\%)

\begin{tabular}{ll}
\hline Nutrients & Values in percent \\
\hline Moisture & $8.70 \pm 0.081$ \\
Dry matter & $91.30 \pm 0.074$ \\
Crude protein & $4.89 \pm 0.041$ \\
Crude fibre & $8.75 \pm 0.040$ \\
Ether extract & $2.15 \pm 0.040$ \\
Ash & $8.93 \pm 0.047$ \\
Metabilizable energy $(\mathrm{kcal} / \mathrm{kg})$ & $2717.96 \pm 0.001$ \\
Nitrogen free extract & $66.56 \pm 0.124$ \\
\hline
\end{tabular}

Values are mean \pm standard deviation.

The amino acid composition of sweet cassava peel is presented in Table 2. The results of the amino acids profile recorded in this study revealed that Glycine $(0.425$ $\%)$, serine $(0.315 \%)$, Proline $(0.218 \%)$, Glutamic acid $(0.176 \%)$, Arginine $(0.140 \%)$ and Aspartic acid (0.108\%) had the highest values. This differs from earlier report of Paul et al. (2016) whose report indicated Leucine and Glutamic acid as the most concentrated amino acids in Cassava peel. Furthermore, the authors reported that cassava and yam tubers contain relatively low amounts of proteins. The minimum threshold index of computed protein efficiency ratio for good quality protein is
1.50 (Friedman, 1996). Thus, computed protein efficiency ratio value $(0.711)$ recorded in this study is below the threshold level hence cassava peel investigated in this study cannot be classified as good quality protein. It is therefore important to enrich cassava peel based diets with quality protein (Afolabi et al., 2012). The least amino acids recorded in this study are Histidine and Tyrosine with value of $0.005 \%$ each. The amino acids values recorded in this study were lower than the values reported by (Aro and Aletor, 2012, Paul et al., (2016) for cassava peels. The variation as earlier stated may be attributed to varietal difference, agronomic practices, geographical location and processing methods. Ogunbode et al. 
(2019) in a study conducted on nutrients and anti - nutrient content of sundried cassava starch extract pulp observed low protein value which was attributed to difference in soil composition and geographical location. The values of proline $(0.072 \%)$, serine $(0.315 \%)$ and methionine
$(0.076 \%)$ recorded in this study were higher than the values of $0.03,0.04$ and 0.03 reported by Julie et al. (2009) for cassava root. The contents of glycine (0.426), cysteine $(0.01)$ and threonine $(0.025)$ were similar to values of $0.40,0.01$ and 0.03 for glycine, cysteine and threonine reported by the authors.

Table 2: Amino acid profile of sweet cassava peels $(\%)$

\begin{tabular}{ll}
\hline Amino acids & Values in percent \\
\hline Arginine & $0.140 \pm 0.001$ \\
Alanine & $0.031 \pm 0.001$ \\
Aspartic acid & $0.108 \pm 0.0008$ \\
Cysteine & $0.01 \pm 0.0004$ \\
Glutamic acid & $0.176 \pm 0.0009$ \\
Glycine & $0.426 \pm 0.0008$ \\
Histidine & $0.005 \pm 0.0008$ \\
Isoleucine & $0.070 \pm 0.0004$ \\
Leucine & $0.067 \pm 0.008$ \\
Lysine & $0.032 \pm 0.0001$ \\
Methionine & $0.076 \pm 0.0001$ \\
Ornithine & $0.103 \pm 0.0008$ \\
Phenylalanine & $0.047 \pm 0.0008$ \\
Pyrolysine & $0.218 \pm 0.001$ \\
Proline & $0.072 \pm 0.0004$ \\
Serine & $0.315 \pm 0.001$ \\
Threonine & $0.025 \pm 0.0004$ \\
Tyrosine & $0.005 \pm 0.0008$ \\
Trytophan & $0.008 \pm 0.0004$ \\
Valine & $0.096 \pm 0.002$ \\
\hline Values are mean
\end{tabular}

Values are mean \pm standard deviation.

The results for mineral composition of Sweet cassava peels are summarized in Table 3. The concentration of Magnesium, iron, lead and zinc were 913.74, 111.50, 1.97 and $2.88 \mathrm{mg} / \mathrm{kg}$ respectively. The magnesium $(913.74 \mathrm{mg} / \mathrm{kg})$ and iron $(111.50 \mathrm{mg} / \mathrm{kg}$ ) was the most abundant mineral present. These values are higher than 236 and $14.7 \mathrm{mg} / \mathrm{kg}$ reported by Aro et al. (2010). The least concentrated mineral obtained in the present study was copper $(0.00031 \%)$. The iron content recorded in this study $(111.50 \mathrm{mg} / \mathrm{kg})$ was higher than
$15 \mathrm{mg} / \mathrm{kg}$ reported by INRA et al. (2012c). The calcium $(0.056 \%)$ and potassium $(0.29 \%)$ values recorded in this study are within the range values of 0.01 to 3.3 and 0.3 to 12.5 reported by INRA et al. (2012c). The sodium $(0.085 \%)$ and phosphorus $(0.09 \%)$ are however lower than values of 0.31 and $2.1 \mathrm{~g} / \mathrm{kg}$ DM reported by INRA et al. (2012c). The values of sodium $(0.085 \%)$, zinc $(2.88 \mathrm{mg} / \mathrm{kg})$ and potassium $(0.29 \%)$ were lower than values of $14 \mathrm{mg} / 100 \mathrm{~g}$, $0.34 \mathrm{mg} / 100 \mathrm{~g}$ and $271 \mathrm{mg} / 100 \mathrm{~g}$ reported by Julie et al. (2009) for cassava root. 
Amaza

Table 3: Some mineral profile of sweet Cassava peels

\begin{tabular}{ll}
\hline Minerals & Values \\
\hline $\mathrm{Ca}(\%)$ & $0.056 \pm 0.004$ \\
$\mathrm{Mg}(\mathrm{mg} / \mathrm{kg})$ & $913.74 \pm 0.008$ \\
$\mathrm{Fe}(\mathrm{mg} / \mathrm{kg})$ & $111.50 \pm 0.004$ \\
$\mathrm{~Pb}(\mathrm{mg} / \mathrm{kg})$ & $1.97 \pm 0.004$ \\
$\mathrm{Zn}(\mathrm{mg} / \mathrm{kg})$ & $2.88 \pm 0.004$ \\
$\mathrm{Cu}(\%)$ & $0.00031 \pm 4.71$ \\
$\mathrm{Mn}(\%)$ & $0.00090 \pm 1.084$ \\
$\mathrm{Na}(\%)$ & $0.085 \pm 0.004$ \\
$\mathrm{~K}(\%)$ & $0.29 \pm 0.004$ \\
$\mathrm{P}(\%)$ & $0.09 \pm 1.387$ \\
$\mathrm{Al}(\mathrm{mg} / \mathrm{kg})$ & $2.1 \pm 0.047$ \\
\hline $\mathrm{Va}$
\end{tabular}

Values are mean \pm standard deviation.

The concentrations of phytochemicals were 26.06, 699.8, 0.063, 24.81, 8.37, $1457 \mathrm{mg} / 100 \mathrm{~g}$ and 2.84 for Saponin, Tannin, hydrogen cyanide, phytate, trypsin inhibitors, alkaloid and oxalate respectively. The phytate, $\mathrm{HCN}$ and oxalate contents reported in this study $24.81,0.063$ and $2.84 \mathrm{mg} / 100 \mathrm{~g}$ were lower than $1.01 \mathrm{mg} / \mathrm{g}, 38.62 \mathrm{mg} / \mathrm{kg}$ and $82.18 \mathrm{mg} / \mathrm{kg}$, $32.9 \mathrm{mg} / \mathrm{kg}$ and $330 \mathrm{mg} / \mathrm{kg}$, reported by (Lamidi and Ogunkule, 2015, Aro et al., 2010). The alkaloid content $1457 \mathrm{mg} / 100 \mathrm{~g}$ recorded in this study was above the upper limit of $60 \mathrm{mg} / 100 \mathrm{~g}$ recommended for a safe feed (MacDonald et al., 1995). The $\mathrm{HCN}$ content $(0.063 \mathrm{mg} / 100 \mathrm{~g})$ of cassava peel was lower than the values of $0.72 \mathrm{mg} / 100 \mathrm{~g}, 32.9 \mathrm{mg} / \mathrm{kg}$ and $37.58 \mathrm{mg} / \mathrm{kg}$ reported by Ezekiel et al. (2010), Aro et al. (2010) and Ogunbode et al. (2019) for unfermented cassava peel, cassava peel and sundried cassava starch extract pulp. Safety limit for cyanide in cassava food is 10 $\mathrm{mg} / \mathrm{kg}$ dry weight and levels below 100 $\mathrm{mg} / \mathrm{kg}$ dry weight are considered safe in cassava chips for feeding to different classes of livestock (FAO and IFAD, 2004). The oxalate content recorded in this study $(2.84 \mathrm{mg} / 100 \mathrm{~g})$ was 1 ower than $27.8 \mathrm{mg} / 100 \mathrm{~g}$ reported for potatoes (Barbara et al., 2009). The values of anti nutrients recorded were all below the threshold of lethal levels and therefore safe for animal consumption. Well-processed cassava peels have generally acceptable levels of HCN below $50 \mathrm{mg} / \mathrm{kg}$ (Osei et al., 1989; Nwokoro et al., 2005).

Table 4: Phytochemicals composition of sweet cassava peels

\begin{tabular}{ll}
\hline Phytochemicals & Values \\
\hline Saponin $(\mathrm{mg} / 100 \mathrm{~g})$ & $26.06 \pm 0.226$ \\
Tannin $(\mathrm{mg} / 100 \mathrm{~g})$ & $699.8 \pm 1.023$ \\
HCN $(\mathrm{mg} / 100 \mathrm{~g})$ & $0.063 \pm 0.009$ \\
Phytate $(\mathrm{mg} / 100 \mathrm{~g})$ & $24.81 \pm 0.035$ \\
Trypsin inhibitor $(\mathrm{Tiu} / \mathrm{mg} / \mathrm{g})$ & $8.37 \pm 0.0169$ \\
Alkaloids $(\mathrm{mg} / 100 \mathrm{~g})$ & $1457 \pm 2.268$ \\
Oxalate $(\mathrm{mg} / 100 \mathrm{~g})$ & $2.84 \pm 0.035$ \\
\hline
\end{tabular}

Values are mean \pm standard deviation

\section{Conclusion}

The results from this study revealed that cassava peel contain appreciable level of NFE (66.56\%) and can serve as energy source. The mineral contents showed that magnesium (913.74mg/kg) and iron $(111.50 \mathrm{mg} / \mathrm{kg})$ are the most highly concentrated minerals. Cassava peels can 
therefore serve as a valuable source of magnesium and iron in livestock feed. The values of anti -nutrients recorded were all below the threshold of lethal levels and therefore safe for animal consumption. The computed protein efficiency ratio value of 0.711 recorded in this study was below the minimum threshold index level of 1.5 for good quality protein. Similarly, its essential amino acids contents were low. It is therefore, recommended that feeding of animals with cassava diets be supplemented with good quality amino acids.

\section{References}

Afolabi, T.A.. Onadeji, R. S., Ogunkunle, O. A. and Bamiro, F.O. 2012. "Comparative analysis of the nutritional quality of browse leaves (Spondias mombin and Albizia saman) and tuber peels (yam and cassava) used as ruminant feeds," Ife Journal of Science, vol. 14, no. 2, pp. 337-344,

Alsmeyer, R. H., Cubningham, A. E.and Happich, M. L.1974,'Equations to predict PER from amino acid analysis" Food technology, volume 28, pp 34-38. Google scholar

Ambrose, A., Zemba, Y. U., and Nankap L. B. 2017. Climatic information as evidence of desertification processes in northern Yobe state, Nigeria: implications for agriculture and ecosystem. Global Journal of Pure and Applied Sciences vol. 24: 117-124

Association of Official Analytical Chemists (AOAC) 1990. Official Methods of Analysis 15th Edition. Association of Official Analytical chemists, Washington D.C. Pp7173.

Apeh, A. O., Emmanuel, U. A., Ze, Y. Z., Fidelis, F. and Paul, A. I. 2017. Improving Cassava Quality for Poultry Feeding Through
Application of Biotechnology. https://www.researchgate.net/publ ication/322567371. Accessed 12 December 2020

Aro, S. O., Aletor, V.O., Tewe, O.O., Agbende, J.O. 2010.Nutritional potentials of cassava tuber waste: A Case study of cassava starch processing factory in south western Nigeria. Livestock Resource for Rural Development 22 (11).

Aro, S. O., Aletor, V. A. 2012. Proximate composition and amino acid profile of differently fermented cassava tuber wastes collected from cassava starch processing factory in Nigeria. Livestock Resource for Rural Development 24 (3).

Ayomide, A. 2018. Researchers list economic uses of cassava peels. The Guardian.13 August 2018

Barbara, B., Beatrice, M., and Ruth, C.' R. 2009. Nutrients, bioactive nonnutrients and anti-nutrients in potatoes. Journal of Food Composition and Analysis 22: 494-502

Cavid, I. F., El-sharkaway, M. A., Acosta, A. and Saneches, T. 1998. Long term effects of mulch, fertilization and Tillage on cassava growth in sandy soils of northern Colombia. Field Crop Research 57: 45-56.

Christopher, I. N., Onyekwe, C. E., Justus I. O. and Nkwoada, A. 2016. The proximate analysis and biochemical composition of the waste peels of three cassava cultivars. International Journal of Scientific Engineering and Applied Science (IJSEAS) - Volume-2, Issue-11,

Etchu, K. A. 1., Tapong, V., Ndamukong, K. and Enokenwa, O. 2019. Substituting Maize for Processed Cassava Peels: A Cost Benefit Analysis in Poultry Farming. 
International Journal of Research in Agricultural Sciences Volume 2, Issue 4, 2348-3997

Ezekiel, O. O., Ogugua, C. A., Hans, P. B. and Thaddeus C. E 2010. Protein enrichment of Cassava peels by submerged fermentation with Trichoderma viride (ATCC 36316). African Journal of Biotechnology Vol. 9 (2), pp. 187194

FAO and IFAD. 2004. The Global Cassava Development Strategy. Cassava for livestock feed in sub-Saharan Africa. The Use of cassava in livestock feeding in West, Eastern, Central and Southern Africa. Food and Agricultural Organization and international Fund for Agricultural $\mathrm{D}$ e $\mathrm{v}$ e 1 o $\mathrm{ftp} / / \mathrm{ftp}$.fao.org/docrep/fao/007/j j1255e/j1255e00.pdf. Accessed December 31, 2020.

FAO and ICRISAT. 2019. Climate-Smart Agriculture in the Yobe State of Nigeria.CSA Country Profiles for Africa Series. International Center for Tropical Agriculture (CIAT); International Crops Research Institute for the Semi-Arid Tropics (ICRISAT); Food and Agriculture Organization of the United Nations (FAO). Rome, Italy. 22p.

Fasset, D. W. 1996. Oxalates In: Toxicants occurring naturally in Foods. National Academy of Science Research Council, Washington D.C, U.S.A

Federal Institute for Industrial Research, Oshodi (FIIRO). 20002004 Annual Reports. Lagos, Nigeria

Heuzé, V. and Tran, G. 2012. Cassava Foliage. Feedipedia.org. A programme by INRA, CIRAD, AFZ and FAO.

ILRI. 2015. Scaling the use of cassava peels as quality livestock feed in
Africa.ILRI Research Proposal Summary. Nairobi, Kenya: ILRI.

INRA, CIRAD, AFZ and FAO. 2012b. Cassava Peels, fresh. Feedipedia Animal Feed Resources I n f o r m a t i o n S y t e m ww.feedipedia.org/node/11944.Ac cessed December 30, 2020.

INRA, CIRAD, AFZ and FAO. 2012c. Cassava tuber, fresh. Feedipedia Animal Feed Resources I $n$ for m a t i o $n$ S y s e m http://www.feedipedia.org/node/1 1946. Accessed December 31, 2020

Julie, A. M. 2009. Nutritional value of Cassava for use as a staple food and recent Advances for Improvement. Comprehensive reviews in food science and food safety 8(3) 181194

Lamidi, A. A. and Ogunkunle, T. 2015. Chemical Composition, Mineral profile and phytochemical properties of common feed resources used for small ruminant animal production in southwest, Nigeria. International Journal of Science and Nature. vol..6(1): $92-96$

Liener, I. E. 1979. The nutritional significance of plant protease inhibitors. Proceedings of Nutrition Society. 38: 109-113

McDonald, P., Edwards, R. A., Greenhalgh, J. F. D. and Morgan, C. A. 1995. Animal Nutrition. 5th Edn., Longman Singapore Publishers (Pvt.) Ltd., Singapore.

Maga, J. A. 1983. Phytate: Its chemistry, occurrence, food interaction, nutritional significance and methods of analysis. Journal of Agriculture Food Chemistry. 30: 19

Monday, A. O., Simon, T. U. and Agbajor, K. G. 2017. Proximate Analysis 
Determination of proximate composition, amino acids, minerals and phytochemical profile of Cassava (Manihot esculenta) peel

and Mineral Composition of Peels of three Sweet Cassava Cultivars. Asian Journal of Physical and Chemical Sciences 3(4): 1-10.

Njoku, D. N., Egesi, C. N., Gracen, V. E, Offei, S. K., Asante, I. K. and Danquah, E.Y.2014. Identification of Pro-vitamin. A Cassava (Manihot esculenta Crantz) Varieties for Adaptation and Adoption through Participatory Research. Journal of Crop Improvement. Vol.28 issue $3 \mathrm{Pp}$ 361-376

National Bureau Statistics (NBS), 2010. Nigeria Poverty Profile. NBS, Abuja

National Population Commission 2006. National Population Census. The president, Abuja.

Nwokoro, S. O., Adegunloye, H. D., Ikhnwina, A. F. 2005. Nutritional composition of cassava sievates collected from some location in south western Nigeria. Pakistan Journal of Nutrition 4(4)257-261

Olugbenga, D. and Oloruntola, 1. 2020. Effect of dietary cassava peel meal supplemented with methionine and multienzyme on hemobiochemical indices, digestibility, and antioxidants in rabbits.The Journal of Basic and Applied $\begin{array}{lllllllllllll}Z & o & o & l & o & g & y & 8 & 1 & : & 3 & 3\end{array}$ https://doi.org/10.1186/s41936020-00170-2

Ogunbode, A. A., Akinosun, A. A., Olajide, T. M. 2019. Nutrients and anti - nutrient content of sundried cassava starch extract pulp. Journal of Applied Science and Environmental Management vol. 23 (6) 1133-1135.

Osai, S. A andTwumasi, J. K. 1989. Effects of oven dried cassava peels meal on the performance and carcass characteristics of broiler chickens. Animal Feed Science

Technology 24(3-4)247-252

Paul, M., Rajindar, D. and Bhupindar, S. 1988. Determination of Both Tannin and Protein in a TanninProtein Complex. Journal of Agricultural chemistry 36(3)

Paul, K. 2015. From food waste to animal feed, Cassava peels potentially big business for $\mathrm{Nigerian}$ women.https://news.ilri.org/2015/ 07/09/from-food-waste-toAnimal-feed-cassava-peelspotentially-big-business-fornigerian-women/3997

Paul, C. C., Chiedozie, O. I., Odinakachi, S., Ferdinand, N. and Chibuike, U. and Nwachukwu 2016. Amino Acid Profiles, Total Nitrogen Contents, and Computed-Protein Efficiency Ratios of Manihot esculenta Root and Dioscorea rotundata. Journal of food processing 2014(5):8

Pauzenga, U. 1985. Feeding Parent Stock. Zoo Technical International. Pp. 22-24.

Sim, E. E. W. E. I. 2011. Isolation and determination of anti-nutritional compounds from root and shells of peanut (Arachis Hypogaea). A project report of Department of Chemical Science Faculty of Science University Tunku Abdul Rahman, 34-35.

Smith, O. B. 1992. A review of Ruminant Responses to cassava based diets. Cassava as Livestock feed in Africa $\begin{array}{lllllllllllll}P & \mathrm{r} & \mathrm{o} & \mathrm{c} & \mathrm{e} & \mathrm{e} & \mathrm{d} & \mathrm{i} & \mathrm{n} & \mathrm{g} & \mathrm{s} & \text { : }\end{array}$ IITA/ILCA/University of Ibadan, Workshop on the Potential Utilization of Cassava as Livestock Feed in Africa (Eds S. K. Hahn, L. Reynolds and G. N. Egbunike). Pp. 39-53.

Sogunle, O. M., Fanimo, A. O., Abiola, S. 
S. and Bamgbose, A. M. 2009. Performance of growing pullets fed cassava peel meal diet supplemented with cashew nut reject meal, Archives Zootechnology, 58 (221): 23-31

United Nations development programme (UNDP) 2018. National Human Development Report 2018: Achieving Human Development in North East Nigeria, Towards an Understanding of the Humanitarian-Development Peace Nexus.
World Food Programme(WFP). 2017. Emergency Food Security Assessment in Three North Eastern States (Borno, Yobe and Adamawa) of Nigeria. Available at https:// docs.wfp.org/api/documents/WFP $-0000062431 /$ download/. Accessed 4th January, 2021.

Received: $30^{\text {th }}$ September, 2020 Accepted: $28^{\text {th }}$ January, 2021 